\title{
A Model Bird Law
}

A CCORDING to a recent release of the National Audubon Society hawks and owls have a lot of friends in Connecticut. That became apparent this fall when the governor signed a model bird protection bill that makes it unlawful to shoot any species of hawk or owl in that state. This places Connecticut among the leaders in bird conservation.

A provision of the new law permits farmers to destroy those individual hawks caught in the act of doing damage to poultry. Pointing out that only occasional hawks develop into poultry stealers, the National Audubon Society said this provision will protect farmers and at the same time prevent misinformed persons from meting out "vigilante justice" to all hawks and owls because of the misdeeds of a few of them.

The National Audubon Society believes the new law will be regarded as a model "because it recognizes that the average person cannot distinguish among the various hawks and owls, hence the statute protects them all except that hawks may be taken when in the act of destroying poultry."

There has been a marked change in public attitude towards birds of prey since the turn of the century. It has not been very long since no legal protection was offered to eagles, hawks and owls throughout Canada and the United States. Extensive studies of the economic relationships of these birds has produced evidence that they are friends of man and play an important role in controlling rodent and insect populations, as well as their general function in the ecological scheme of things.

The growing army of hobbyists who observe birds has become increasingly impressed with the grace and skill of the birds of prey and has joined with conservation and form organizations to support legislation protecting hawks and owls.

This movement has resulted in definite action in all but six of the states to the south of us, and we feel that similar legislation should be enacted throughout Canada. 'The BLUE JAY expresses the hope that a committee of the Saskatchewan National History Society be set up in the near future to make an extensive study of the Connecticut legislation, and that that committee approach the Saskatchewan government with the request that they enact legislation similar to the "model" bird law of Connecticut.

\section{Some Winter Friends}

\section{Ronald Hooper, Somme}

AST winter when my.brother and

I had a camp in the bush, we had many opportunities to observe Nature. We always ate with the shack door open and the Black-capped Chickadees and Canacia Jays would come in and eat the crumbs we dropped. Blue Jays, Pine Grosbeaks, Redpolls and Juncos fed nearby in the straw where we fed the horses.

One day we cut a piece of rind, about a foot square, from a piece of pork and nailed it to a tree in front of the door. In a few minutes the Chickadees were busy on it, and a White-breasted Nuthatch ran down the tree to enjoy the feast. They were interrupted however by the arrival of a Hairy Woodpecker.
After pecking awhile, the thrifty fellow would drop to the ground and eat the scraps he had dropped. Soon he seemied to have his fill, so he grabbed the rind and tried to pull it from the tree. When this didn't work, he cocked his head back and viewed the situation more thoroughly. He then pecked all around the nail until the rind fell to the ground, and would have flown away with it had we not stopped him.

Another time I put a fish-head on a stump. A red squirrel came along. and he, like the woodpecker, seemed to eat on it until he was filled. Then he picked it up in his mouth and ran throligh the bush with it (it was as big as he was). When he tried to run up a tree with it he fell over backwards so he was contented to pull it under a fallen tree.

I am looking forward to seeing my little friends again this winter. 